ROMAN PUYDA,

\title{
THE STRUGGLE OF THE SOVIET AUTHORITY AGAINST THE «REMNANTS OF UNIAT» IN THE UKRAINIAN SSR AT THE BREAK OF THE 1970s - 1980s
}

\begin{abstract}
The key methods of the Ukrainian SSR party authorities to counter the attempts of reviving the Ukrainian Greek Catholic Church in the western Ukrainian regions at the break of the 80s-90s of the XX century were considered. It was noted that in the late 1970s in this region, particularly in Galicia, Greek-Catholic believers and the clergy measurably intensified their activity, which was evident mainly in houses of worship attendance, traditional rites observance, letters issued to the Council for Religious Affairs of the Soviet Union Ministers with the requirement to register religious communities, clandestine ordination of the clergy, etc. It was stated that in order to counter the religious influence intensification of the Russian Orthodox Church on the population, as well as to prevent negative anti-social manifestations of «remnants of Uniat», local Communist Party committees and Soviet authorities carried out a number of propaganda and mass political events to expose anti-Soviet religious ideology, in particular, «the reactionary role of the Uniat Church in the history of the Ukrainian people». It was noted that the Communist Party of Ukraine took concrete measures to step up anti-religious propaganda in Western Ukrainian regions, as well as to promote the advantages of the Soviet mode of life. It was alleged that the activities of Greek Catholic believers were discussed at the Council for Religious Affairs of the Soviet Union Ministers sessions of the Ukrainian SSR in the regions of Western Ukraine, party rallies at different levels, meetings of the ideological activists of the regions, seminars of cultural and educational workers, district and regional atheist conferences. It was noted that the Communist Party of Ukraine paid considerable attention to the media, which should have covered the historical aspects of the «anti-popular backbone of Uniat Church».
\end{abstract}

Keywords: Ukrainian SSR; Ukrainian Greek Catholic Church; western Ukrainian regions; The Communist Party of Ukraine; repressions; persecutions; believers.

Introduction

The establishment of Soviet regime in the Western Ukrainian regions during the Second World War (19391941) and the post-war period (1944-1991) fundamentally changed the religion-state relations field. During this period, the Ukrainian Greek Catholic Church (UGCC), as a result of outrageous repressive pressure of the Soviet authorities on believers and the clergy, ceased activities in their homeland for decades. However, the forcible reunification with the Russian Orthodox Church (ROC) did not shake the faith of the Greek-Catholics in the possibility of renewing the full functioning of their Church in the Ukrainian Soviet Socialist Republic (Ukrainian SSR), which in the second half of the 1960s - the first half of the 1980 s led to a growing animosity of religion-state relations in Galicia. In the memorandum report «On the activities of the Uniat clergy in the Lviv oblast» (1970), the authorized representative of the Council for Religious Affairs of the Soviet Union Ministers of the Ukrainian SSR reported that in 1968 «the Uniat clergy... stepped up their activities. They seized several dozens of previously

ISSN 1728-9343 (Print)

ISSN 2411-3093 (Online) locked churches, increased the number of worship services that were celebrated by Uniat priests in the private apartments of citizens» ${ }^{1}$. Moving forward, the situation in the church-religious sphere only got more complicated for the authorities.

For more than a year now, state-church relations in the Ukrainian SSR have been in the field of view of Ukrainian historians, theologists, philosophers, political scientists, who have revealed certain aspects of the issue over the past thirty years. Integrating scientific researches as a whole reflect the broad picture of the policy of the Central Committee of the Communist Party of the Soviet Union (the CPSU Central Committee) in the religious sphere, in particular, it is noticeable in the studies of O. Bazhan, Y. Danilyuk (2000), V. Pashchenko (2002), V. Marchuk (2004), V. Voynalovych (2005), P. Bondarchuk (2012) and others, however, not enough attention has been paid to the local characteristics of certain re-

\footnotetext{
${ }^{1}$ State Archives of Lviv Region. Fund P-1332. List 2. File 43. Page 21.
}

SKHID Vol. 2 (2) July-August 2021 
gions, in particular Galicia, as the main field of the spread of Greek Catholicism.

Purpose of the article - to define the methods of the Soviet government's struggle against the «remnants of Uniat» in the western Ukrainian regions in the late 1970s and early 1980 s.

\section{Materials and Method}

The methodological framework of the article was general scientific (analysis and synthesis, induction and deduction) and special scientific (scientific description, quantitative analysis, critical analysis, comparison of analogies, classification, typological analysis, conceptualization, etc.) methods.

\section{Results and Discussio}

In the minds of party officials of the Ukrainian SSR, the UGCC was associated with the «surreptitious church», which left no theoretical chance for the legalization of its church and religious structures in the USSR. The party-state authorities kept up struggling the believers and the clergy of the UGCC, as they were aware that the Church, driven into catacombs, continued in operation underground. On top of repressions and persecutions of believers, which has already been sufficiently described in Ukrainian and diaspora historiography, the authorities also used other forms of opposition to the spread of the Greek Catholic faith across the population of the region.

Undoubtedly, one of the most important for the Communist Party of Ukraine (CPU) remained to be propaganda activities, in particular the pretentious celebrations of the Lviv church council anniversaries.

Thus, the information of the Central Committee of the Communist Party of Ukraine «On events related to the 30th anniversary of the Lviv church council» (marked "confidential») states the magniloquence of the celebrations, which took place on May 14-15, 1976 in Lviv and confined to the liquidation of the Greek Catholic Church. In particular, the diocesan administration held sessions dedicated to the anniversary of the church council, which were attended by Deputy Chairman of the Council for Religious Affairs under the Council of Ministers of the Ukrainian SSR P. Pylypenko, Commissioner for Religious Affairs under the Council of Ministers of the Ukrainian SSR in Lviv oblast B. Inshin, representatives of the clergy of Lviv-Ternopil diocese. The report of Metropolitan Archbishop Nicholas and the speeches of attendees disclosed the "hostile activities of the union over a span of 350 years of its existence», laid emphasis upon the "adventurism and efforts of the Vatican to instill Catholicity in the western regions of Ukraine», considered the «reactionary role of the Uniat Church during the German occupation and its cooperation with fascists, Ukrainian bourgeois nationalists. $\nu^{2}$. The participants of the event stressed the need to intensify the struggle for ideological education of the population as well. It was noted that the local (Lviv) party organization registered the believers of the UGCC and improved the educational work in those settlements where Greek Catholic believers and clergy displayed activity. Lectures were organized in the cities and districts of

\footnotetext{
${ }^{2}$ State Archives of Lviv Region. Fund P-3. List 34. File 85. Page 1.

СХІД Том 2 (2) липень-серпень 2021 р.
}

the region, theoretic conferences on «The reactionary role of the Uniat Church in the history of the Ukrainian people» were held.

Lviv Regional Committee of the Communist Party of Ukraine was outraged by the fact that the speeches of the ministers of religion showed «temporization to the spirit and patriotic feelings of the Soviet people, as they associated all these events with higher calling of God, construed in their own fashion, unscientifically». However, according to party officials, «no deviations and violations were committed ${ }^{3}$.

No less grandiosely were the ceremonial events in celebration of the 35th anniversary of the Lviv pseudocouncil (1981). Not only party authorities, but also 150 clergymen of the Russian Orthodox Church arrived in Lviv for the ceremony, including Metropolitan Archbishop of Kyiv and Galicia, Exarch of Ukraine Philaret, Metropolitan Archbishop of Odessa and Kherson Serhiy, Episcopus Seraphim of Pinza and Saransk, Episcopus of Pinsk, Vicar Athanasius of Minsk diocese. According to the local commissioner of the Council for Religious Affairs under the Council of Ministers of the Ukrainian SSR, the event was attended by local clergy, including 45 former Greek Catholic priests, 27 people were participants in the Lviv pseudo-council of 1946. On May 16, 1981, a solemn academy was held, during which the Exarch of Ukraine Filaret, Metropolitan Archbishop of Lviv and Ternopil Nicholas spoke. The reports revealed the «historical significance of the Lviv Cathedral in the liquidation of the Union of Brest» and outlined «the struggle of the clergy and the believers against the Greek Catholic Church» ${ }^{4}$.

Taking into consideration the fact that «many former Greek Catholic believers began to attend Orthodox churches and participate in Orthodox rites», ${ }^{5}$ state and party authorities in the early 1980s aimed significant efforts at combating the piteousness of the population. Additionally, the communists of the region really had cause for alarm - there was a consistent trend to hold religious customs in the western Ukrainian regions. In particular, in Ivano-Frankivsk oblast out of the total number of 1340 newborns, 633 children were baptized $(47 \%)$ in 1982 . At the same time, 108 couples (17\%) were wedded in church, and funerals with the participation of clergy took place in $88 \%$ of cases. The staff of the local commissioner of the Council for Religious Affairs under the Council of Ministers of the Ukrainian SSR noted the fact of participation in the rite of baptism and wedding of members of the All-Union Leninist Young Communist League (AULYCL, Komsomol $)^{6}$. To counter the spread of Uniat, local authorities carried out inspections of the lawfulness of the purchase of housing and residence permit of clergy and believers. In particular, respective Commission in Kolomyia (Ivano-Frankivsk oblast) in 1979 detected that the city was inhabited by: two widows of «former» Greek Catholic priests of retirement age; six orphans of «former» Greek

\footnotetext{
${ }^{3}$ State Archives of Lviv Region. Fund P-3. List 34. File 85. Page 2.

${ }^{4}$ Central State Archive of the highest authorities and administration of Ukraine. Fund 4648. List 6. File 162. Page 33.

${ }^{5}$ State Archives of Ivano-Frankivsk region. Fund P-388. List 1. File 39. Page 25.

${ }^{6}$ Central State Archive of the highest authorities and administration of Ukraine. Fund 4648. List 8. File 207. Page 160.
} 
Catholic priests, five of which were retired and one was a housewife; twelve widows and two orphans of retired Orthodox priests; eight Greek Catholic priests of retirement age who did not convert to Orthodoxy. The commission also detected that 17 Orthodox priests live in Kolomyia. The commission did not reveal any facts of illegal registration ${ }^{7}$.

Perhaps the most difficult situation for the IvanoFrankivsk Regional Committee of the Communist Party was in Holyn village, Kolomyia district, Ivano-Frankivsk oblast, where local believers guarded the seized house of worship round-the-clock. During the prayer gatherings, believers used Greek Catholic paraphernalia, including samizdat (outlaw underground press). An accumulator storage battery was used for the interior lighting of the building. During the service, the priest often demanded to legalize the activities of this religious community ${ }^{8}$.

The anti-Uniat campaign in the Lviv oblast was also noted as large-scale. Thuswise, on January 13, 1981, the Central Committee of the Communist Party of Ukraine prepared a secret report «On the implementation of the resolution of the Central Committee of the CPSU «On further improvements of ideological, political and educational work» and "On the status and measures to improve lecture propaganda» in party organizations of the Lviv oblast», in which the achievements of the Lviv regional committee of the Communist Party of Ukraine in the field of lecture work were highlighted. It was noted that universities of lecturers and seminars (created jointly by the propaganda and agitation department of the regional party committee and the board of the regional organization of the "Znannya» Society), devoted to the problems of the Soviet way of life and modern ideological struggle, continued to operate effectively: «Lenin's National Policy of the CPSU and the criticism of its bourgeois nationalist falsifications", "The foreign policy of the CPSU and the modern international situation of the USSR», etc. Lecturers' zonal seminars have become an important form of informing the population. In December 1980 in Lviv, Drohobych, Sambor, Stryi, Chervonohrad, Busk, Gorodok, Zolochev, Novy Rozdol such seminars were held, which were devoted to the project of the CPSU Central Committee «On the main directions of economic and social development of the USSR 1981 - 1985 and for the period until 1990» (about 4,000 people took part in seminars). In total, more than 25,000 lecturers were retrained at 85 regional seminars held in $1980^{\circ}$.

It should be mentioned that the lecture and propaganda work of the local party militants in practical terms remained at a rather low level, as noted by the members of the Bureau of the Lviv Regional Committee of the Communist Party (1981). It was stated that the district committees of the party, the Soviet and administrative authorities of Horodok, Stryj, and Yavoriv districts underestimated "the commitment of Uniat extremists in their attempts to intensify the Catholic Church, and restore Uniat», lost political urgency in these matters, made gross miscalcula-

\footnotetext{
${ }^{7}$ Central State Archive of the highest authorities and administration of Ukraine. Fund 4648. List 6. File 162. Page 43.

${ }^{8}$ Central State Archive of the highest authorities and administration of Ukraine. Fund 4648. List 6. File 162. Page 21.

9 State Archives of Lviv Region. Fund P-3. List 46. File 84. Page 2-3.
}

ISSN 1728-9343 (Print)

ISSN 2411-3093 (Online) tions in educational work among the population. It has been noted that for a long time in the villages of Myshana, Zavadiv, and Muzhilovychi, Uniat supporters held mass gatherings on religious basis, created conflict situations, constantly disturbed public order, and invited former Uniat priests to meet their religious needs. District party committees failed to give the principal evaluation to unlawful actions of "remnants of Uniat», did not provide clear coordination efforts of party organizations, government administrative bodies. The public activists of these villages behaved passively, lost political vigilance, did not inform the party and Soviet authorities about the situation that had developed in these villages, and did not oppose attempts of religious extremists to restore Uniatism. Political and educational work in Zavadov, Mshan, Muzhilovichi, as well as in other villages of these districts, was conducted formally, individual work with believers was neglected, public opinion of labor collectives where Uniat worked was not used at all ${ }^{10}$.

Under the circumstances in the Lviv oblast, the local regional committee of the CPU considered it necessary: 1. To hold regional city and district seminars-workshops of the party-Soviet ideological active in the issues of control over the observance of the legislation on cults, cessation of attempts to activate the Catholic Church and restore Uniatism; 2. To discuss at the bureau of city and district committees of the party the issues of restructuring the atheistic upbringing of the population, strengthening control over the observance of the legislation on cults, termination of the activity of «remnants of Uniat»; 3. To take into account all the Uniat supporters, religious fanaticism and extremism, to organize with them specifically purposeful ideological work. To create operative groups in the settlements from among the employees of the Soviets, administrative bodies, members of the voluntary citizen patrol and ideological assets; 4 . To analyze the activities of cultural and public education institutions in all settlements where the Uniates were active, to strengthen their material base, to establish quarterly control over the implementation of the outlined measures ${ }^{11}$.

The Lviv Regional Committee of the Communist Party stated in a report "On serious deficiencies in counteracting attempts to intensify the Catholic Church and Restore Uniatism in the villages of Mshana in Horodotskyi, Zavadiv in Stryiskyi, Muzhylovychi, Yavorivskyi districts» (1981), that under the influence of Uniate extremists, some believers in the village of Mshana, Horodok district, have been raising the issue of registering the so-called Eastern Rite Catholic Church since 1978, constantly organizing a gathering of believers near an abandoned religious building, and disturbing public order in the village. The party organization, the board of the communal farm «Lenin's Testament», the executive committee of the village council did not take decisive measures to stop the illegal actions of the supporters of Uniatism, did not seek the installation of a religious building for the needs of the farmstead. Atheistic work was often replaced by occasional educational activities. In the villages of Zavadov

\footnotetext{
${ }^{10}$ State Archives of Lviv Region. Fund P-3. List 58. File 63. Page 2.

${ }^{11}$ State Archives of Lviv Region. Fund P-3. List 58. File 63. Page 2.
}

SKHID Vol. 2 (2) July-August 2021 
and Muzhilovichi, religious associations actually ceased their activities, but the local authorities did not take timely care of the removal from registration of religious buildings and did not use them for the needs of the establishment. The «remnants of Uniat» took advantage of this and began to open churches on their own and hold services in the villages with the participation of extremist Uniate priests. The resumption of the activities of the Orthodox community in the village of Zavadiv did not lead to restrictions on the activities of the Uniat ${ }^{12}$.

Representatives of the above-mentioned settlements of the Lviv oblast were present in Moscow on February 17-19, 1981, in order to visit the Council for Religious Affairs under the Council of Ministers of the USSR. Greek Catholics demanded the registration of the Eastern Rite Catholic Church ${ }^{13}$. After this trip, the Council for Religious Affairs under the Council of Ministers of the USSR muchcriticised the Lviv Regional Committee of the Communist Party and the Lviv City Committee of the Communist Party, as approximately 70 Greek Catholic priests lived in Lviv and regularly visited villages in Horodok, Yavoriv, and Stryj districts. In the apartments of some of them, according to the findings of the law enforcement agencies, so-called "home churches» were equipped, religious rites were held, "home monasteries» functioned, and youths were being prepared for the adoption of monkery. Greek Catholic prayer books, calendars, and religious objects were traded near churches, food markets, cemeteries of the city of Lviv and regional centers ${ }^{14}$.

On March 31, 1981, the Lviv regional committee of the Communist Party informed about the implementation of the Resolution of the Bureau of the regional committee of the Communist Party «On serious shortcomings in counteracting attempts to intensify the Catholic Church and restore Uniatism in the villages of Mshana in Horodotsky, Zavadiv Stryisky, Muzhilovichi, Yavoriv districts». It was noted that ideological activists, members of the commission for assisting republics to comply with Soviet legislation on religious cults, employees of internal affairs authorities kept 117 addresses under constant control where former Greek Catholic priests, monks and nuns lived, repeatedly visited their residences, had preventive conversations with them. It was stated that the Communist Party of Ukraine consistently analyzed the activities of the clergy of the city's churches, constantly worked on improvement of the search for effective forms and means of exposing the anti-popular essence of Uniat. In particular, in the central lecture hall of the city organization of the «Znannya» society two courses of lectures were given «Uniat: ideology, politics» and «Catholicism: ideology, politics». Throughout 1981, in cooperation with creative unions, 6 actors' reading conferences from the course «Ideology, Politics, Contemporary» were organized ${ }^{15}$. City committees and district committees of the CPSU, which were not discussed in the title of the resolution «On serious shortcomings in counteracting attempts to intensify

\footnotetext{
12 State Archives of Lviv Region. Fund P-3. List 58. File 63. Page 7-8.

${ }_{13}$ State Archives of Lviv Region. Fund P-3. List 58. File 63. Page 9.

14 Ibid.

${ }^{15}$ State Archives of Lviv Region. Fund P-3. List 58. File 63. Page 18.

СХІД Том 2 (2) липень-серпень 2021 р.
}

the Catholic Church and restore Uniatism in the villages of Mshana in Horodotsky, Zavadiv Stryisky, Muzhilovichi, Yavoriv districts» also reported on the implementation of the Resolution of the Bureau of the Regional Committee of the Communist Party of Ukraine. In particular, the Boryslavsky City Committee of the Communist Party of Ukraine informed that lecturers from the "Znannya» Society were giving lectures in labor collectives, which covered the anti-popular activities of the Uniat Church in Ukraine, clarified the policy of the CPSU and the Soviet state in the field of religion and church, criticized religious fanaticism and extremism. It was also noted that «proUniat elements in the city were not observed ${ }^{16}$.

To suppress the Uniates, the Soviet government made extensive use of the capabilities of the Orthodox clergy, which is especially noticeable in the example of Zakarpattia. ${ }^{17}$ The actual church-religious situation in the Zakarpattia oblast clearly demonstrates the methods of the Soviet government's struggle with the Greek Catholic believers - to neutralize the latter, the Soviet-party authorities used the Russian Orthodox Church. Thus, on November 23, 1982, a meeting was held with the participation of the first deputy chairman of the Council for Religious Affairs under the Council of Ministers of the Ukrainian SSR P. Pilipenko, the Commissioner for the Council for Religious Affairs in the Zakarpattian oblast I. Vashchints, the senior inspector of the Office of the Authorized Council for Religious Affairs in the Zakarpattian oblast V. Panov, Deputy Chairman of the Executive Committee of the Mukachevo City Council of People's Deputies M. Popovich and Bishop Savva. P. Pilipenko noted that in September 1981 two important issues were discussed with Bishop Savva. The first of them concerned the fact that in the Mukachevo-Uzhgorod diocese «a struggle against remnants of Uniat in Orthodox ranks is being waged at a low level, » specific examples were given of a church in the village of Dragovo, Khust district, where an Orthodox cross was removed from the bannerol and a Greek Catholic cross was sewn on, and the church in the village of Volovets, where priest Ivanitsky conducted a crucession on Easter with elements of the Greek Catholic cult ${ }^{18}$.

The second question concerned the fact that 16 graduates of theological seminaries were not employed in the diocese ${ }^{19}$. In response, the bishop noted that after his arrival from Kiev and the last conversation with members of the Council for Religious Affairs under the Council of Ministers of the Ukrainian SSR, «nothing has been done». He stated that the graduates of theological seminaries will keep on being unemployed due to the opposition of the local authorized Council for Religious Affairs. In an aggressive manner, P. Pilipenko noted that the office of the Commissioner for Religious Affairs under the Council of Ministers of the Ukrainian SSR in the Zakarpattian oblast «is not a personnel department in the field of employment of clergymen.» "You are well aware of the

\footnotetext{
${ }^{16}$ State Archives of Lviv Region. Fund P-3. List 58. File 63. Page 95.

${ }^{17}$ State Archives of Ivano-Frankivsk region. Fund P-388. List 1. File 39. Page 23.

${ }^{18}$ Central State Archive of the highest authorities and administration of Ukraine. Fund 4648. List 7. File 217. Page 21.

${ }^{19}$ lbid.
} 
procedure for appointing priests to parishes, which has developed in practice and is observed by all bishops of the exarchate», said the representative of the Council. Why do you ignore it? Why did you not agree on the list of graduates of the seminary who had arrived in Zakarpattia with the authorized person, gave all the priests' decrees on their appointment to parishes, and went on vacation yourself? ${ }^{20}$. After listening to the answer of Bishop Savva («we have more than 70 parishes where there are no priests»), P. Pilipenko stated: «lf you, Alexander Pavlovich, put the question this way and do not want to solve it yourself, then we can put the question before the exarchate and the patriarchy so that this question would be decided here by another bishop. You show stubbornness that is not needed by either the Church, or you, or the state» $^{21}$

Having failed to reach an agreement on the issue of employment of graduates of theological seminaries in the Zakarpattian oblast, P. Pilipenko touched upon another, no less important issue - opposition to the spread of Uniat. «In Kiev, we talked a lot about the fight against remnants of Uniat, and at the same time, we have a lot of facts indicating that white Uniat candles are used in a number of parishes ... Uniat attributes are preserved,» said the representative of the Council. - You did not take action regarding Minajlo, Ivanets and others ... I am citing fresh facts - today we stopped at a church in the village of Nove Davydkovo. There are Uniate icons, bannerols and service books. Those clergimen need to be put out and replaced with other priests under the supervision of experienced Orthodox priests». In response, Bishop Savva stated: "When I have fired all the Orthodox priests, who will I stay with? With some Uniates? We'll see what kind of rearrangement we do. We will agree on that with the Authorized Representative .... ${ }^{22}$. He also added that Ivanitsky «went to considerable lengths to eliminate Uniat: he rebuilt the cathedra, took away icons and bannerols, but it is difficult for him during patronal festivals they sell Uniat icons and calendars around the church». P. Pilipenko asked a rhetorical question: "The global issue for Zakarpattia is the fight against Uniatism. Who should deal with this issue?» And heard the unequivocal answer of Bishop Savva: «Me!». The latter also noted that he could not find a «knowledgeable Orthodox priest» instead of Minailo and when he finds one, he will replace him. Concluding the conversation, Bishop Savva summed up: «Why don't you have such a conversation with the Exarch of Ukraine. We are cut off from Orthodoxy by Uniatism - the neighborhood of Lvov and Ivano-Frankivsk regions on the one side and Romania and Poland on the other» $^{23}$

\section{Conclusion}

In the 1970s - the first half of the 1980s, the UGCC, driven into the catacombs, did not stop functioning in the Ukrainian SSR, as stated in secret documents of the security forces, the local regional committee of the Communist Party of Ukraine, reports of representatives of the Council for Religious Affairs under the Council of Ministers of the USSR. To counteract the spread of Greek Catholicism in the western region, the government widely used propaganda methods among the local population, the capabilities of the Russian Orthodox Church, applied repression to the most active believers and clergy. However, despite the measures taken, the Uniat did not lose hope for the restoration of the functioning of the Church in the Ukrainian SSR, as evidenced by their numerous letters to party officials demanding to open the closed religious buildings, register religious communities (formally Orthodox), unauthorized churches in certain areas of the region, observance of the Greek Catholic religious rites, underground ordination of the clergy.

\section{REFERENCES}

Bazhan, O., Danyljuk, V. (2000). Vyprobuvannja viroju: borotjba za realizaciju prav $i$ svobod virujuchykh v Ukrajini $v$ drughij polovyni 1950-1980-kh rr. [The Test of Faith: The Struggle for the Realization of the Rights and Freedoms of Believers in Ukraine in the Second Half of the 1950s and 1980s]. Kyiv. (In Ukrainian)

Bondarchuk, P. (2012). Relighijna svidomistj virujuchykh URSR (1940-1980-i roky): povsjakdenni projavy, transformaciji [Religious consciousness of believers of the USSR (19401980s): everyday manifestations, transformations]. Kyiv. (In Ukrainian)

Central State Archive of the highest authorities and administration of Ukraine.

Marchuk, V. (2004). Cerkva, dukhovnistj, nacija. Ukrajinsjka ghreko-katolycjka cerkva v suspiljnomu zhytti Ukrajiny KhKh st. [Church, spirituality, nation. Ukrainian Greek Catholic Church in the public life of Ukraine in the twentieth century.]. Ivano-Frankivsjk. (In Ukrainian).

Pashhenko, V. (2002). Ghreko-katolyky v Ukrajini. Vid 40-kh rr. KhKh st. do nashykh dniv [Greek Catholics in Ukraine. From the 40's of the twentieth century. to this day]. Poltava. (In Ukrainian)

State Archives of Ivano-Frankivsk region.

State Archives of Lviv Region.

Vojnalovych, V. (2005). Partijno-derzhavna polityka shhodo relighiji ta relighijnykh instytucij v Ukrajini 1940 - 1960-kh rokiv: politologhichnyj dyskurs [Party-State Policy on Religion and Religious Institutions in Ukraine in the 1940s and 1960s: Political Science Discourse]. Kyiv. (In Ukrainian)

\footnotetext{
${ }^{20}$ lbid.

${ }^{21}$ Central State Archive of the highest authorities and administration of Ukraine. Fund 4648. List 7. File 217. Page 22.

${ }^{22}$ Central State Archive of the highest authorities and administration of Ukraine. Fund 4648. List 7. File 217. Page 24.

${ }^{23}$ Central State Archive of the highest authorities and administration of Ukraine. Fund 4648. List 7. File 217. Page 27.
}

ISSN 1728-9343 (Print)

ISSN 2411-3093 (Online) 
Роман Пуйда,

Івано-Франківський національний технічний університет нафти і газу (м. Івано-Франківськ, Украйна)

e-mail: puida@ukr.net, ORCID: 0000-0003-0438-9415

\section{БОРОТЬБА РАДЯНСЬКОЇ ВЛАДИ ІЗ «ЗАЛИШКАМИ УНІАТСТВА» В УКРАЇ̈СЬКІЙ РСР НА ЗЛАМІ 1970-х - 1980-х рp.}

Розглянуто основні методи протидії радянсько-партійних органів влади Української РСР спробам відродження Української греко-католицької церкви у західноукраїнських областях на зламі 80-x - 90-х рp. XX ст. Відзначено, що наприкінці 1970-х рр. у регіоні, насамперед Галичині, значно активізували діяльність греко-католицькі віруючі та духовенство, що проявлялося, насамперед, у відвідуванні культових споруд, дотриманні традиційної обрядовості, надсиланні листів до Ради у справах релігій при Раді Міністрів СРСР 3 вимогою зареєструвати релігійні громади, підпільному висвяченні духівництва та ін. Констатовано, що 3 метою протидії активізації релігійного впливу на населення Російської православної церкви, а також запобігання негативних антигромадських проявів «залишків уніатства», місцеві Компартійні комітети, радянські органи влади проводили низку пропагандистських і масових політичних заходів щодо викриття антирадянської релігійної ідеології, зокрема «реакційної ролі уніатської церкви в історії українського народу». Зазначено, що Комуністична партія України проводила конкретні заходи щодо посилення антирелігійної пропаганди у західноукраїнських областях, а також пропаганди переваг радянського способу життя. Доведено, що діяльність греко-католицьких віруючих обговорювалася на нарадах Уповноважених Ради у справах релігій при Раді Міністрів УРСР у областях Західної України, партійних зборах різних рівнів, зборах ідеологічного активу районів, семінарах культпросвітніх працівників, обласних, районних атеїстичних конференціях. Відзначено, що значну увагу Компартія України приділяла 3MI, які мали б висвітлювати історичні аспекти «антинародної суті уніатства».

Ключові слова: УРСР; Українська греко-католицька церква; західноукраїнські області; Компартія України; репресії; переслідування; віруючі.

(C) Roman Puyda

Надійшла до редакції: 19.07.2021

Прийнята до друку: 06.08.2021 